\title{
Law, language and the multilingual state
}

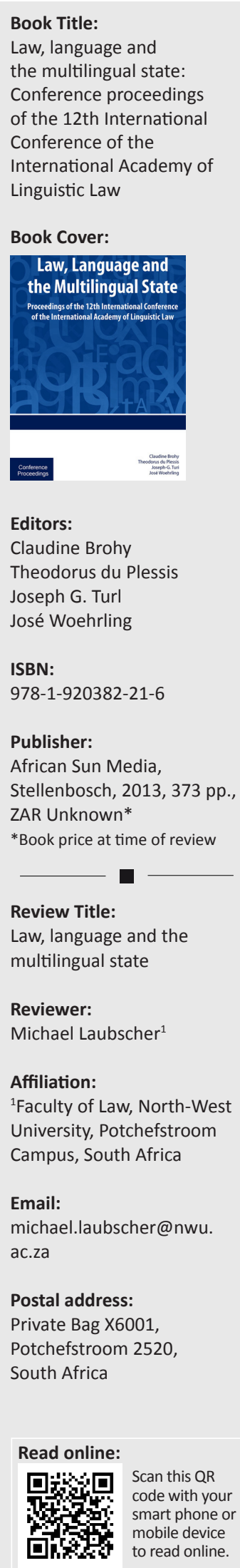

This publication contains a selection of papers delivered at the 12th International Conference of the International Academy of Linguistic Law (IALL-AIDL) held in South Africa. The foreword to this publication indicates that the IALL-AIDL is an organisation established in Montreal and Paris in September 1984 to deal with the phenomena and problems pertaining to the world linguistic diversity as well as law and language, especially comparative linguistic law (or language law). Comparative linguistic law refers to the different legal and linguistic norms pertinent to the law of language, the language of law and linguistic rights (also called language rights).

The theme of the conference was to investigate the state-juridical challenges facing multilingual societies; as such, it drew contributions from Wales, France, Africa and Canada, to name a few. Underlining the importance of multilingualism, and given the organisation's French roots one assumes, some of the contributions are wholly in French (except for an English abstract at the start of the discussion).

Topics vary from a survey on language policies and legislation in Africa to obstacles to the establishment of a truly multilingual South African state, from a model of protection and promotion of minority languages in Italy to a discussion of a language barometer to gauge citizens' attitudes towards bilingualism, amongst others.

Chumbow makes a very good case for the increased establishment and execution of language policies in Africa, which seems to be lagging behind its European and American counterparts. He notes that linguistic rights cannot be seen merely as moral obligations; they need to be backed by the force of the law. Strydom adds to this by outlining obstacles in the way of a multilingual South African state, whilst Turi deals with the ways in which governments deal with legally recognising languages and giving it official status.

The issue of the official status of a language and what this implies in a multilingual state receives considerable attention in various contributions, with Lourens taking the South African government to task for their failure to live up to the obligations and expectations of Section 6 of the South African constitution. As he states: there is no point in affording a language official status and then never actually actively and in the form of positive actions promoting the usage of these official languages in the public arena. He goes on to point out that multilingualism is the cornerstone of a democratic state and can provide essential added value and vision to the South African constitution.

Doucet offers a very interesting account of how the state of New Brunswick, which has two official languages, English and French, deals with language rights. It becomes clear from his discussion that to establish legislative measures for multilingualism is not enough; the actual practical and enforcement of these measures must lead to substantive equality, which proves to be quite a challenge. Williams and $\mathrm{O}^{\prime}$ Flaharty offer more insight into such practical application with their discussion of the functioning of the office of the Language Commissioner in Ireland. This office must, in general, monitor compliance by public bodies with the provisions of the Official Languages Act, and has proved to be fairly successful, despite some obvious weaknesses. Similar language commissioners are found in Wales and Canada, with various degrees of success it seems, but this model could be a very useful one for other countries dealing with multilingualism.

Everyone seems to be in agreement that linguistic rights are fundamental rights for all, but the burning question seems to be how these rights are properly recognised and practically applied. If practical and meaningful application of these linguistic rights does not occur, linguistic rights could end up offering nothing more than mere legislative window dressing.

How to cite this book review: Laubscher, M., 2014, 'Law, language and the multilingual state', Literator 35(2), Art. \#1106, 2 pages. http:// dx.doi.org/10.4102/lit.v35i2.1106

Copyright: (C 2014. The Authors. Licensee: AOSIS OpenJournals. This work is licensed under the Creative Commons Attribution License. 
The focus of the conference was the state-juridical challenges facing multilingual societies, and as such most of the contributions tackle linguistic law issues. To some this might not be fascinating reading material, but the issue of a multilingual society, and all the challenges it brings, remains a fundamental and crucial issue worldwide. We live in a globalised world comprising of many different languages and cultures, and the linguistic issues that stem from this must be dealt with in many ways, the juridical way being one of them. That is where this publication's value lies - it touches on language law and the challenges it offers to governments, public organisations and language groups. It also investigates the practical implications of language law, with specific reference to multilingualism. The fact that various contributions from various continents and various languages are brought together in one publication adds to its value.

Linguists, jurists, legislators, social scientists and many others will benefit from the discussions offered in this publication and it is hoped that they will embrace the issues, and the value, of multilingualism with renewed fervour. 